JURNAL ILMU KESEHATAN BHAKTI HUSADA:

HEALTH SCIENCES JOURNAL

VOL. 12 NO. 02, DESEMBER 2021

DOI: $10.34305 / \mathrm{JIKBH} . \mathrm{V} 12 \mathrm{I} 2.339$
Ciptaan disebarluaskan di bawah

Lisensi Creative Commons Atribusi-

NonKomersial-BerbagiSerupa 4.0

Internasional.

\title{
ANALISIS PENERAPAN PROTOKOL KESEHATAN PADA ANAK DI ERA PANDEMI COVID-19
}

\author{
Setianingsih, Novi Indrayati \\ STIKes Kendal \\ ningsihsetia9988@gmail.com
}

\begin{abstract}
Abstrak
Pandemi virus corona (COVID-19) di Indonesia menyerang seluruh kelompok usia termasuk anak-anak. Angka kejadian COVID-19 pada anak mencapai 5\% dari total kejadian. Manifestasi klinis COVID-19 pada anak-anak seringkali menyerupai penyakit musiman seperti demam, batuk, flu dan diare, sehingga orang tua mengabaikan kondisi anak tanpa disadari gejala tersebut merupakan ancaman penyebaran COVID-19 yang paling kecil dalam lingkup sosial karena anak-anak merupakan kelompok usia rentan terpapar COVID-19. Orang tua dituntut untuk dapat mempersiapkan anak -anak agar meminimalisir paparan virus COVID-19 dengan memaksimalkan penerapan protokol kesehatan dalam kehidupan sehari-hari. Penelitian bertujuan mendeskripsikan penerapan protokol kesehatan pada anak di masa pandemi COVID19. Jenis penelitian ini adalah deskriptif kuantitatif yaitu menggambarkan karakteristik responden serta menganalisis penerapan protokol kesehatan yang telah dilakukan orang tua kepada anak selama masa pandemi COVID-19. Instrumen penelitian menggunakan kuesioner karakteristik responden dan penerapan protokol kesehatan. Sampel dalam penelitian ini berjumlah 266 orang tua yang memiliki anak sekolah dasar di wilayah kecamatan kota Kendal dengan teknik pengambilan sampel purposive sampling. Hasil penelitian menunjukkan bahwa median umur anak adalah 9 tahun dengan umur termuda 6 tahun dan umur tertua 12 tahun, mayoritas anak berjenis kelamin perempuan sebanyak 144 orang $(54,1 \%)$, pendidikan terakhir orang tua adalah Perguruan Tinggi sebanyak 124 orang (46,6 \%) dan sebagian besar pekerjaan orang tua adalah swasta sebanyak $127(47,7 \%)$, mayoritas orang tua telah menerapkan protokol kesehatan kepada anak sebanyak 261 (98,1\%). Diharapkan penerapan cuci tangan dengan air mengalir, tidak hanya menggunakan hand sanitizer terutama ketika tangan tampak kotor dan berminyak, namun dilakukan dengan menggunakan air mengalir dan sabun.
\end{abstract}


JURNAL ILMU KESEHATAN BHAKTI HUSADA:

HEALTH SCIENCES JOURNAL

VOL. 12 NO. 02, DESEMBER 2021

DOI: $10.34305 / \mathrm{JIKBH} . \mathrm{V} 12 \mathrm{I} 2.339$
Ciptaan disebarluaskan di bawah

Lisensi Creative Commons Atribusi-

NonKomersial-BerbagiSerupa 4.0 Internasional.

Kata kunci: Protokol kesehatan, Orang tua, Anak, COVID-19

\section{Pendahuluan}

Infeksi virus corona telah menyebar ke seluruh negara di dunia, salah satunya adalah Indonesia sehingga World Health Organization (WHO) menyatakan sebagai darurat kesehatan. Infeksi ini dapat menyerang semua usia bahkan anak-anak. Angka kejadian corona pada anak-anak tidak sebesar pada orang dewasa namun, orang tua harus tetap waspada. Hasil studi literatur melaporkan bahwa, gejala COVID-19 pada kelompok anak pada umumnya lebih rendah dan ringan apabila dibandingkan dengan kelompok dewasa dan prognosis pada anak yang terpapar COVID-19 menunjukkan respon terapi yang baik dan waktu pemulihan yang lebih cepat dibandingkan orang dewasa. Mayoritas gejala yang muncul adalah batuk, faring hiperemis, dan demam. Hasil studi literatur juga menyatakan bahwa belum ada laporan atau bukti jelas mengenai kejadian transmisi COVID 19 melalui intrauterine (Anantyo et al., 2020).

Ketua Pengurus Pusat Ikatan Dokter Anak Indonesia (IDAI) menyatakan bahwa angka kejadian COVID-19 pada anak di
Indonesia meningkat 11-12 persen bahkan, selama masa pandemi, jumlah kematian anak balita meningkatkan hingga 50 persen atau ada 1.000 kematian pada anak setiap minggunya. dr. Citra Indriani, MPH., Epidemiolog UGM, menyatakan bahwa anak-anak mempunyai risiko untuk terinfeksi COVID-19 dan melaporkan bawah kasus pertama COVID-19 di DIY adalah anak-anak (Grehenson, 2021).

Ketua IDAI, Aman Bhakti Pulungan menyatakan bahwa kematian anak yang diakibatkan COVID-19 di Indonesia merupakan tertinggi di dunia, $12,5 \%$ dari total kasus COVID-19 nasional diantaranya adalah anak usia 0 hingga 18 tahun, hal Ini menunjukkan bahwa satu dari delapan kasus COVID-19 di Indonesia merupakan anakanak (Supriatin, 2021). Angka kejadian corona hingga tanggal 27 Oktober 2020 di Indonesia sebanyak 396.454 kasus positif dan sebanyak 13.512 orang meninggal dunia (Satuan Tugas Penanganan COVID-19, 2020). Kendal merupakan salah satu kota di Jawa Tengah dengan angka kejadian corona tertinggi yaitu sebanyak 1447 kasus positif 
JURNAL ILMU KESEHATAN BHAKTI HUSADA:

HEALTH SCIENCES JOURNAL

VOL. 12 NO. 02, DESEMBER 2021

DOI: $10.34305 / \mathrm{JIKBH} . \mathrm{V} 12 \mathrm{I} 2.339$

dan 63 orang meninggal dunia (Dinas

Kesehatan Kabupaten Kendal, 2020).

COVID-19 pada anak, sebagian besar bergejala ringan atau bahkan tanpa gejala, keadaan ini menyebabkan status infeksi COVID-19 anggota keluarga penting untuk dideteksi dengan pemeriksaan PCR, terutama pada anak (Felicia, 2020). Pusat Pengendalian dan Pencegahan Penyakit di Amerika merevisi pernyataan bahwa gejala COVID-19 pada anak tidak fatal menjadi gejala pada anak terinfeksi virus corona menyerupai kondisi Multisystem Inflammatory Syndrome in Children (MISC) dimana organ vital anak meradang seperti area jantung, paru-paru, otak, ginjal, kulit, mata hingga pencernaan, keadaan ini dapat menyebabkan kematian namun, penanganan awal yang baik dapat mencegah kejadian tersebut.

Pemerintah menerbitkan peraturan terkait era kehidupan baru (new normal) di tengah pandemi COVID-19, hal ini menuntut orang tua untuk mempersiapkan anak-anak dari paparan virus COVID-19 yaitu dengan menerapkan protokol kesehatan dalam kehidupan sehari-hari. New normal tetap menerapkan pembatasan sosial, diam dirumah, dan menjaga jarak untuk menghindari penularan virus corona.

\section{Ciptaan disebarluaskan di bawah \\ Lisensi Creative Commons Atribusi- \\ NonKomersial-BerbagiSerupa 4.0 Internasional.}

Anak yang sedang sakit terutama demam, batuk, pilek, diare harus tetap berada di rumah. Anak sekolah dasar memiliki tingkat mobilitas yang tinggi. Berdasarkan wawancara pada 7 dari 10 orang tua yang memiliki anak SD di wilayah Kendal menyatakan bahwa belum sepenuhnya menerapkan protokol kesehatan pada anak ketika mengajak keluar rumah meskipun Kendal merupakan salah satu daerah dengan zona merah.

Hasil penelitian menunjukkan bahwa 97\% masyarakat pernah mendapatkan informasi tentang COVID-19 baik dari pemerintah yang memberikan edukasi maupun melalui berbagai macam, media namun hal ini belum diketahui apakah sudah diimbangi dengan perilaku masyarakat yang mengutamakan pencegahan penyakit COVID-19 (Fatmawati \& Hendrayani, 2020). Beberapa fenomena yang ada membuat peneliti tertarik melakukan penelitian tentang "Analisis Penerapan Protokol Kesehatan pada Anak di Era Pandemi COVID-19"

\section{Metode}

Desain penelitian menggunakan deskriptif kuantitatif untuk menggambarkan karakteristik responden 
JURNAL ILMU KESEHATAN BHAKTI HUSADA:

HEALTH SCIENCES JOURNAL

VOL. 12 NO. 02, DESEMBER 2021

DOI: $10.34305 / \mathrm{JIKBH} . \mathrm{V} 12 \mathrm{I} 2.339$

serta menganalisis penerapan protokol kesehatan yang dilakukan orang tua kepada anak selama masa pandemi COVID-19. Alat ukur menggunakan kuesioner karakteristik responden yang meliputi usia, jenis kelamin, tingkat pendidikan dan jenis pekerjaan serta kuesioner tentang penerapan protokol kesehatan yang meliputi penerapan penggunaan masker, mencuci tangan dan menjaga jarak. Sampel dalam penelitian ini
Ciptaan disebarluaskan di bawah Lisensi Creative Commons AtribusiNonKomersial-BerbagiSerupa 4.0 Internasional. berjumlah 266 orang tua yang memiliki anak sekolah dasar negeri di wilayah kecamatan kota Kendal dengan teknik pengambilan sampel purposive sampling.

\section{Hasil dan Pembahasan}

Hasil penelitian tentang karakteristik demografi dan penerapan protokol kesehatan pada anak Sekolah Dasar.

Tabel 1. Tendensi sentral umur anak di SDN Kecamatan Kota Kendal $(n=266)$

\begin{tabular}{ccccc}
\hline Variabel & Median & Standar deviasi & Minimum & Maximum \\
\hline Usia & 9 & 1,770 & 6 & 12 \\
\hline
\end{tabular}

Tabel 1 menunjukkan bahwa median usia anak adalah 9 tahun dengan usia termuda 6 tahun dan usia tertua 12 tahun.

Tabel 2. Distribusi frekuensi karakteristik anak berdasarkan jenis kelamin di SDN Kecamatan Kota Kendal $(n=266)$

\begin{tabular}{ccc}
\hline Variabel & Frekuensi (f) & Persentase (\%) \\
\hline Jenis kelamin anak & & \\
Laki-laki & 122 & $45,9 \%$ \\
Perempuan & 144 & $54,1 \%$ \\
\hline Total & $\mathbf{2 6 6}$ & $\mathbf{1 0 0 , 0}$ \\
\hline
\end{tabular}

Tabel 2 menunjukkan bahwa mayoritas anak berjenis kelamin perempuan sebanyak 144 orang $(54,1 \%)$.

Tabel 3. Distribusi frekuensi karakteristik orang tua berdasarkan tingkat pendidikan terakhir dan pekerjaan orang tua di SDN Kecamatan Kota Kendal $(n=266)$

\begin{tabular}{lcc}
\hline Variabel & Frekuensi (f) & Persentase (\%) \\
\hline Pendidikan & & \\
SD & 52 & $19,5 \%$ \\
SMP & 4 & $1,6 \%$ \\
SMA & 86 & $32,3 \%$ \\
PT & 124 & $46,6 \%$
\end{tabular}


JURNAL ILMU KESEHATAN BHAKTI HUSADA:

HEALTH SCIENCES JOURNAL

VOL. 12 NO. 02, DESEMBER 2021

DOI: $10.34305 / \mathrm{JIKBH} . \mathrm{V} 12 \mathrm{I} 2.339$
Ciptaan disebarluaskan di bawah

Lisensi Creative Commons Atribusi-

NonKomersial-BerbagiSerupa 4.0 Internasional.

\begin{tabular}{lcc} 
Pekerjaan & & \\
Swasta & 127 & $47,7 \%$ \\
PNS & 85 & $32 \%$ \\
Buruh & 10 & $27,2 \%$ \\
Petani & 2 & $0,8 \%$ \\
Lainnya & 25 & $9,4 \%$ \\
\hline Total & $\mathbf{2 6 6}$ & $\mathbf{1 0 0 , 0}$ \\
\hline
\end{tabular}

Tabel 3 menunjukkan bahwa mayoritas pendidikan terakhir orang tua adalah Perguruan Tinggi sebanyak 124 orang $(46,6 \%)$ dan sebagian besar pekerjaan orang tua adalah swasta sebanyak $127(47,7 \%)$.

Tabel 4. Distribusi frekuensi penerapan protokol kesehatan pada anak di SDN Kecamatan Kota Kendal $(n=266)$

\begin{tabular}{lcc}
\hline Penerapan Protokol Kesehatan & Frekuensi & Persentase (\%) \\
\hline Baik & 261 & $98,1 \%$ \\
Kurang Baik & 5 & $1,9 \%$ \\
\hline Total & $\mathbf{2 6 6}$ & $\mathbf{1 0 0 , 0}$ \\
\hline
\end{tabular}

Tabel 4 menunjukkan hasil analisis didapatkan bahwa mayoritas orang tua telah menerapkan protokol kesehatan kepada anak sebanyak $261(98,1 \%)$.

Tabel 5. Distribusi frekuensi penerapan protokol kesehatan $(3 \mathrm{M})$ pada anak di SDN Kecamatan Kota Kendal $(\mathbf{n}=\mathbf{2 6 6})$

\begin{tabular}{lcc}
\hline Variabel & Frekuensi & Persentase (\%) \\
\hline Memakai Masker & & \\
Baik & 255 & $95.5 \%$ \\
Kurang baik & 11 & $4.1 \%$ \\
Mencuci Tangan & 235 & $88.3 \%$ \\
$\quad$ Baik & 31 & $11.7 \%$ \\
$\quad$ Kurang baik & 250 & $94.0 \%$ \\
Menjaga Jarak & 16 & $6.0 \%$ \\
$\quad$ Baik & $\mathbf{2 6 6}$ & $\mathbf{1 0 0}$ \\
Kurang baik & &
\end{tabular}

Tabel 5 menjelaskan bahwa Hasil penelitian menunjukkan bahwa penerapan protokol kesehatan dalam hal mencuci tangan masih kurang baik sebesar $11,7 \%$ dan mayoritas penerapan pemakaian masker dalam kategori baik sebesar 95,5 \%. median usia anak adalah 9 tahun dengan usia paling muda 6 tahun dan usia paling tua adalah 12 tahun. Usia seseorang yang semakin bertambah akan semakin matang 
JURNAL ILMU KESEHATAN BHAKTI HUSADA:

HEALTH SCIENCES JOURNAL

VOL. 12 NO. 02, DESEMBER 2021

DOI: $10.34305 / \mathrm{JIKBH} . \mathrm{V} 12 \mathrm{I} 2.339$

dan dewasa, hal ini tidak hanya berkaitan dengan perubahan fisik saja melainkan psikologis atau mental dan kemampuan berpikir juga dapat mengalami perubahan. Usia dapat mempengaruhi pengetahuan seseorang, sedangkan pengetahuan dapat mempengaruhi kepatuhan seseorang sehingga, usia dapat berhubungan dengan kepatuhan seseorang terhadap suatu peraturan (Muhith et al., 2021).

Jenis kelamin anak sebagian besar adalah perempuan (54,1\%). Lawrence Green dalam Notoatmodjo (2005) menjelaskan bahwa redisposing dapat mempengaruhi kepatuhan seseorang karena hal ini merupakan faktor dasar motivasi atau niat seseorang untuk melakukan suatu hal sedangkan, yang termasuk faktor pendorong salah satunya adalah jenis kelamin (Notoatmodjo, 2005). Teori tersebut didukung dengan penelitian Budury (2020) pada mahasiswa keperawatan, yang menyatakan bahwa jenis kelamin tidak berhubungan terhadap penerapan protokol pengendalian COVID-19. Penelitian lain yang mendukung dinyatakan oleh Muhith et al., (2021) bahwa jenis kelamin tidak ada hubungannya dengan penerapan protokol kesehatan, penelitian ini mayoritas berjenis kelamin perempuan, namun saat situasi dan
Ciptaan disebarluaskan di bawah Lisensi Creative Commons AtribusiNonKomersial-BerbagiSerupa 4.0 Internasional.

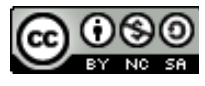

kondisi seseorang merasa terancam serta muncul kesadaran bahwa hidup sehat untuk menghindari penyakit adalah hal yang sangat penting maka akan timbul motivasi untuk patuh terhadap penerapan protokol kesehatan yang ada baik pada perempuan atau laki-laki (Muhith et al., 2021).

Hasil penelitian ini sebagian besar pendidikan terakhir orang tua adalah Perguruan Tinggi sebanyak 124 orang (46,6 $\%$ ). Tingkat pendidikan yang semakin tinggi dapat mempermudah seseorang dalam mendapatkan dan memahami informasi. Semakin tinggi tingkat pendidikan seseorang, maka semakin mudah dalam mendapatkan informasi, dan memahami tentang COVID-19 sehingga, semakin luas pengetahuannya tentang COVID-19.

Penelitian sebelumnya oleh Wiranti et al., (2020) menyatakan bahwa faktor yang secara statistik memiliki hubungan dengan kepatuhan masyarakat terhadap kebijakan Pembatasan Sosial Berskala Besar di Kota Depok, salah satunya yaitu tingkat pendidikan (Wiranti et al., 2020). Hal ini disebabkan tingkat pendidikan seseorang mempengaruhi cara berpikir, proses belajar dan kemampuan menerima arahan, sikap, motivasi dan kemampuan beradaptasi. Responden penelitian ini didominasi oleh 
JURNAL ILMU KESEHATAN BHAKTI HUSADA:

HEALTH SCIENCES JOURNAL

VOL. 12 NO. 02, DESEMBER 2021

DOI: $10.34305 / \mathrm{JIKBH} . \mathrm{V} 12 \mathrm{I} 2.339$

responden yang berpendidikan tinggi, yang juga berarti kecenderungan untuk mematuhi peraturan secara sadar lebih mungkin. Kesadaran akan pentingnya hidup sehat ada dan menjadi pondasi utama dalam menjalankan protokol kesehatan COVID19. Sehingga, para orang tua dapat menerapkan protokol kesehatan dengan baik kepada anaknya.

World Health Organization (WHO) menetapkan COVID-19 sebagai pandemi, sehingga seluruh masyarakat di dunia mempercayai COVID-19 dapat menyerang siapa saja dan dari negara mana saja. Keadaan darurat kesehatan COVID-19 mengharuskan seluruh negara di dunia untuk mengantisipasi dan memberikan respon serta harus meningkatkan kewaspadaan. Tahun 2020, perkembangan penularan virus COVID-19 terjadi secara signifikan karena, penyebarannya sudah universal sehingga, seluruh negara merasakan dampaknya tidak terkecuali negara Indonesia.

Surat edaran Mendikbud Nomor 36962/MPK.A/HK/2020 tentang pembelajaran secara daring dan bekerja dari rumah dalam rangka pencegahan penyebaran Coronavirus disease (COVID19) secara resmi dikeluarkan oleh pemerintah pusat, kebijakan ini berdampak

\section{Ciptaan disebarluaskan di bawah \\ Lisensi Creative Commons Atribusi- \\ NonKomersial-BerbagiSerupa 4.0 Internasional.}

pada sistem pembelajaran. Aktivitas belajar di sekolah beralih menjadi Aktivitas Belajar dari Rumah atau BDR. Kebijakan ini memaksa guru untuk tetap bekerja dari rumah dan murid belajar dari rumah mulai dari jenjang PAUD sampai dengan Perguruan Tinggi. Dampak dari kebijakan pemerintah tentang adanya larangan Pertemuan Tatap Muka (PTM) dengan beralih ke BDR, hal ini tentu tidak hanya berdampak pada guru dan murid namun, orang tua berperan penting untuk optimalisasi dalam pelaksanaan BDR. Pada masa pandemi COVID-19, anak-anak termasuk dalam kelompok usia yang relatif rentan terkena paparan virus corona. Hal tersebut menjadi kewaspadaan mengingat era new normal telah diberlakukan oleh pemerintah Indonesia. Tingkat penularan COVID-19 pada anak-anak di Indonesia masuk dalam kategori cukup tinggi sehingga perlu perhatian orang tua untuk dapat menerapkan protokol kesehatan pada anak agar terhindar dari paparan virus corona, sehingga peran keluarga semakin penting dalam mengasuh, merawat dan mendidik anak, keadaan ini mengembalikan fungsi awal keluarga yaitu sebagai pusat segala kegiatan, tempat terjadinya pendidikan yang utama untuk anak (Kurniati et al., 2020). 
JURNAL ILMU KESEHATAN BHAKTI HUSADA:

HEALTH SCIENCES JOURNAL

VOL. 12 NO. 02, DESEMBER 2021

DOI: $10.34305 / \mathrm{JIKBH} . \mathrm{V} 12 \mathrm{I} 2.339$

Pandemi COVID-19 menyebabkan orang tua menjadi semakin ansietas dengan kesehatan anak-anak. Setiap orang tua menginginkan anaknya selalu dalam keadaan sehat meskipun di era pandemic COVID-19. Upaya yang dapat dilakukan orang tua salah satunya adalah adalah mengingatkan anak-anak untuk selalu menerapkan pola hidup sehat dan bersih (PHBS), agar terhindar dari berbagai penyakit khususnya mencegah tertular COVID-19. Orang tua dapat mengajarkan anak untuk memahami dan menerapkan protokol kesehatan sebagai tindakan awal untuk pencegahan penularan Covi-19. Sejalan dengan yang diungkapkan oleh Rompas et al., (2018) yang menyatakan bahwa mendidik anak merupakan peran penting sebagai orang tua dalam keluarga. Orang tua harus mampu menjadi role model yang baik untuk anak, serta mampu memberikan peringatan, nasihat dan mengarahkan anak agar anak dapat hidup bersih dan sehat (Rompas et al., 2018).

Peran orang tua dalam menjaga dan memastikan agar anak tetap sehat, serta menerapkan pola hidup sehat dengan benar, hal ini sejalan dengan pendapat Ihsani \& Santoso (2020) yang menyatakan bahwa peran orang tua di rumah merupakan hal

\section{Ciptaan disebarluaskan di bawah \\ Lisensi Creative Commons Atribusi- \\ NonKomersial-BerbagiSerupa 4.0 Internasional. \\ (c) (i) (2) (2)}

yang sangat penting dalam memberikan edukasi kepada anak untuk selalu menjaga kebersihan lingkungan, memberikan contoh untuk selalu mencuci tangan setelah beraktivitas di luar, hal tersebut dinilai penting untuk meningkatkan kesadaran mengenai kebersihan lingkungan (Ihsani \& Santoso, 2020). Orang tua berperan dalam membimbing sikap serta keterampilan yang mendasar, seperti pendidikan agama untuk patuh terhadap aturan, dan untuk pembiasaan yang baik namun peran tersebut meluas seperti memberikan contoh dan mengingatkan anak untuk selalu menerapkan protokol kesehatan selama pandemi COVID-19 (Nurlaeni \& Juniarti, 2017).

Upaya memutus mata rantai penularan COVID-19 diperlukan dari berbagai pihak dan multidisiplin, salah satunya adalah dunia pendidikan. Besarnya jumlah populasi pekerja di bidang pendidikan atau tenaga pendidik dan tenaga kependidikan serta peserta didik, yang memiliki mobilitas serta interaksi yang cukup tinggi di sekolah atau ditempat kerja hal ini menyebabkan dunia pendidikan merupakan salah satu pihak yang sangat berkontribusi besar dalam memutus mata rantai penularan COVID-19. Sekolah 
JURNAL ILMU KESEHATAN BHAKTI HUSADA:

HEALTH SCIENCES JOURNAL

VOL. 12 NO. 02, DESEMBER 2021

DOI: $10.34305 / \mathrm{JIKBH} . \mathrm{V} 12 \mathrm{I} 2.339$

menjadi tempat interaksi dan berkumpulnya banyak orang, hal ini merupakan faktor risiko tinggi penyebab penularan COVID19, sehingga perlu adanya antisipasi dalam mencegah dan memutus mata rantai penyebaran COVID-19 di lingkungan sekolah atau tempat kerja tersebut (Wijanarko et al., 2021).

Pandemi COVID 19, dapat menjangkit seluruh kelompok usia termasuk anak-anak. anak-anak adalah kelompok usia yang rentan tertular COVID-19. Tindakan pencegahan disosialisasikan dan diterapkan untuk menjaga anak-anak dari penularan COVID-19. Sejak dini anak-anak dapat diperkenalkan rasa tanggung jawab serta peduli terhadap diri sendiri dan lingkungan (Wardhani et al., 2020). Penerapan protokol kesehatan pada anak dilakukan sebagai upaya pencegahan terhadap paparan virus corona. Bentuk protokol kesehatan yang telah diterapkan orang tua pada anak yaitu mengajari anak cara mencuci tangan dengan benar, membiasakan anak menggunakan masker, menganjurkan anak untuk tetap berada di rumah, dan mengajari anak untuk menutup mulut dengan tisu saat bersin atau batuk, jangan menyentuh mulut, mata, dan hidung sebelum mencuci tangan.
Ciptaan disebarluaskan di bawah

Lisensi Creative Commons Atribusi-

NonKomersial-BerbagiSerupa 4.0 Internasional.

Upaya tersebut telah dituangkan dalam pertanyaan kuesioner, walaupun mayoritas orang tua telah menerapkan protokol kesehatan dengan baik namun masih ditemukan sebaran jawaban orang tua yang masih kurang tepat dalam penerapan protokol kesehatan pada anak terlihat dari jawaban kuesioner anak saya membersihkan tangan menggunakan hand sanitizer karena efektif digunakan ketika tangan tampak kotor dan berminyak sebanyak 168 orang $(63,2 \%)$ dan anak saya tetap bermain di luar rumah sebanyak 136 orang $(51,1 \%)$ serta apabila anak saya menggunakan masker kain, sebaiknya menggunakan masker kain 3 lapis sebanyak $214(81,5 \%)$.

Hasil penelitian sejalan dengan penelitian tentang pengenalan protokol kesehatan pada anak melalui penerapan metode pembelajaran hasilnya penerapan model pembelajaran kooperatif tipe jigsaw lebih efektif dalam meningkatkan pengenalan protokol kesehatan anak usia dini, dibandingkan dengan model pembelajaran konvensional. Protokol kesehatan yang dikenalkan adalah $3 \mathrm{M}$ yaitu menggunakan masker, mencuci tangan dengan sabun dan menjaga jarak (Suryaningsih \& Poerwati, 2021). 
JURNAL ILMU KESEHATAN BHAKTI HUSADA:

HEALTH SCIENCES JOURNAL

VOL. 12 NO. 02, DESEMBER 2021

DOI: $10.34305 / \mathrm{JIKBH} . \mathrm{V} 12 \mathrm{I} 2.339$

Penerapan protokol kesehatan pada anak penting untuk dilakukan di Desa Adat Seminyak dalam bentuk pemberian poster edukasi menggunakan masker, menjaga jarak dan mencuci tangan menggunakan sabun. Penyesuaian sistem penerapan kegiatan latihan dengan protokol kesehatan yang dilakukan adalah membagi waktu dan family instrument gamelan untuk mengurangi jumlah personil pada kegiatan latihan sehingga tidak perlu lagi melibatkan personil dalam jumlah besar, menyemprotkan cairan desinfektan pada alat-alat gamelan secara berkala, menerapkan sistem jaga jarak, mewajibkan peserta untuk menggunakan masker pada kegiatan latihan serta dan mewajibkan peserta untuk selalu rajin mencuci tangan (Payuyasa \& Surya, 2020).

\section{Kesimpulan dan Saran}

Hasil uji statistik menunjukkan bahwa median usia anak adalah 9 tahun dengan umur termuda 6 tahun dan usia tertua 12 tahun, mayoritas anak berjenis kelamin perempuan sebanyak 144 orang $(54,1 \%)$, pendidikan terakhir orang tua adalah Perguruan Tinggi sebanyak 124 orang (46,6 $\%$ ) dan sebagian besar pekerjaan orang tua adalah swasta sebanyak 127 (47,7 \%),
Ciptaan disebarluaskan di bawah

Lisensi Creative Commons Atribusi-

NonKomersial-BerbagiSerupa 4.0 Internasional.

mayoritas orang tua telah menerapkan protokol kesehatan kepada anak sebanyak $261(98,1 \%)$.

Mengingat masih terdapat $11,7 \%$ penerapan protokol kesehatan yang kurang baik maka diharapkan adanya peningkatan dalam hal mencuci tangan yaitu membersihkan tangan tidak hanya menggunakan hand sanitizer terutama digunakan ketika tangan tampak kotor dan berminyak, namun dilakukan dengan mencuci tangan menggunakan sabun dengan air yang mengalir.

\section{Daftar Pustaka}

Anantyo, D. T., Kusumaningrum, A. A., Rini, A. E., Radityo, A. N., Rahardjani, K. B., \& Sarosa, G. I. (2020). Coronavirus Disease 2019 (COVID19) Pada Anak (Studi Literatur). Medica Hospitalia: Journal of Clinical Medicine, 7(1A), 344-360.

Budury, S. (2020). Faktor yang Berhubungan dengan Penerapan Protokol Pengendalian COVID-19 pada Mahasiswa Keperawatan. Jurnal Keperawatan, 12(4), 751-756.

Dinas Kesehatan Kabupaten Kendal. (2020). Data Persebaran COVID-19 dan Rumah Isolasi Mandiri Desa PPKM Kab. Kendal.

Corona.Kendalkab.Go.Id. https://corona.kendalkab.go.id/

Fatmawati, A., \& Hendrayani, S. Y. (2020). 
JURNAL ILMU KESEHATAN BHAKTI HUSADA:

HEALTH SCIENCES JOURNAL

VOL. 12 NO. 02, DESEMBER 2021

DOI: $10.34305 / \mathrm{JIKBH} . \mathrm{V} 12 \mathrm{I} 2.339$

The Risk Perception of Covid-19 in Indonesia. Jurnal Vokasi Keperawatan (JVK), 3(2), 103-108.

Felicia, F. V. (2020). Manifestasi Klinis Infeksi COVID-19 pada Anak. Cermin Dunia Kedokteran, 47(8), 420-423.

Grehenson, G. (2021). Kasus Covid pada Anak Meningkat, Prokes Anak dan Orang Tua Jadi Andalan. Universitas Gadjah Mada.

Ihsani, I., \& Santoso, M. B. (2020). Edukasi Sanitasi Lingkungan dengan Menerapkan Perilaku Hidup Bersih dan Sehat (PHBS) pada Kelompok Usia Prasekolah di Taman Asuh Anak Muslim Ar-Ridho Tasikmalaya. Prosiding Penelitian Dan Pengabdian Kepada Masyarakat, 6(3), 289. https://doi.org/10.24198/jppm.v6i3.22 987

Kurniati, E., Alfaeni, D. K. N., \& Andriani, F. (2020). Analisis Peran Orang Tua dalam Mendampingi Anak di Masa Pandemi Covid-19. Jurnal Obsesi: Jurnal Pendidikan Anak Usia Dini, 5(1), 241-256.

Muhith, S., Ekawati, D., Rosalina, S., \& Zaman, C. (2021). Analisis Kepatuhan Penerapan Protokol Kesehatan COVID-19. Jurnal'Aisyiyah Medika, $6(2)$.

Notoatmodjo, S. (2005). Pengantar Kesehatan dan Ilmu Perilaku. Yogyakarta: Andi Offset.

Nurlaeni, N., \& Juniarti, Y. (2017). Peran Orang Tua dalam Mengembangkan Kemampuan Bahasa pada Anak Usia 4-
Ciptaan disebarluaskan di bawah

Lisensi Creative Commons Atribusi-

NonKomersial-BerbagiSerupa 4.0 Internasional.

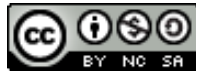

6 Tahun. Jurnal Pelita PAUD, 2(1), 51-62.

Payuyasa, I. N., \& Surya, I. G. A. (2020). Penerapan Protokol Kesehatan dalam Latihan Menabuh bagi Anak-Anak di Desa Adat Seminyak. Segara Widya: Jurnal Penelitian Seni, 8(2), 100-107.

Rompas, R., Ismanto, A. Y., \& Oroh, W. (2018). Hubungan Peran Orang Tua dengan Perilaku Hidup Bersih dan Sehat Anak Usia Sekolah di SD Inpres Talikuran Kecamatan Kawangkoan Utara. Jurnal Keperawatan, 6(1).

Satuan Tugas Penanganan COVID-19. (2020). Peta Sebaran COVID-19. Covid19.Go.Id.

https://covid19.go.id/peta-sebaran

Supriatin. (2021). IDAI: Kematian Anak Indonesia Akibat COVID-19 Tertinggi di Dunia. Merdeka.Com. https://www.merdeka.com/peristiwa/id ai-kematian-anak-akibat-covid-19-diri-tertinggi-di-dunia.html

Suryaningsih, N. M. A., \& Poerwati, C. E. (2021). Pengenalan Protokol Kesehatan pada Anak Usia Melalui Penerapan Model Pembelajaran Kooperatif Tipe Jigsaw. Seminar Ilmiah Nasional Teknologi, Sains, dan Sosial Humaniora (SINTESA).

Wardhani, D. K., Susilorini, M. R., Angghita, L. J., \& Ismail, A. (2020). Edukasi Pencegahan Penularan COVID-19 pada Anak Usia Dini Melalui Media Pembelajaran Audio Visual. Jurnal Abdidas, 1(3), 131-136.

Wijanarko, A., Setiawan, Y., \& Efendi, R. 
JURNAL ILMU KESEHATAN BHAKTI HUSADA:

HEALTH SCIENCES JOURNAL

VOL. 12 NO. 02, DESEMBER 2021

DOI: $10.34305 / \mathrm{JIKBH} . \mathrm{V} 12 \mathrm{I} 2.339$
Ciptaan disebarluaskan di bawah

Lisensi Creative Commons Atribusi-

NonKomersial-BerbagiSerupa 4.0

Internasional.

(2021). Optimalisasi Pelaksanaan

Penerapan Protokol Kesehatan

Penanganan COVID-19 Pada Fase

New Normal Melalui Literasi Media di

SDIT Iqra 1 Bengkulu. Abdi Reksa, 2(1), 51-58.

Wiranti, W., Sriatmi, A., \& Kusumastuti, W. (2020). Determinan Kepatuhan Masyarakat Kota Depok terhadap Kebijakan Pembatasan Sosial Berskala Besar dalam Pencegahan COVID-19. Jurnal Kebijakan Kesehatan Indonesia: JKKI, 9(3), 117-124. 